\title{
KARAKTERISASI KULIT KAYU TINGI (Ceriops tagal) SEBAGAI BAHAN PENYAMAK NABATI
}

\section{CHARACTERIZATION OF TINGI (Ceriops tagal) BARK AS VEGETABLE TANNING MATERIAL}

\author{
Emiliana Kasmudjiastuti \\ Balai Besar Kulit, Karet, dan Plastik, Jl. Sokonandi No. 9 Yogyakarta 55166, Indonesia \\ Telp.: +62 274 512929, 563939; Fax.: +62 274563655 \\ E-mail: emil_bbkkp@yahoo.com
}

Diterima: 24 Februari 2014 Direvisi: 31 Oktober $2014 \quad$ Disetujui: 5 November 2014

\begin{abstract}
Tingi (Ceriops tagal) bark was highly potential as tanning materials due to high tannin concentration. The aim of the study was to determine the characterization of properties of tanning material made from tingi bark, including the tannin levels, the non-tannin levels, the tannin type, the absorption level of the solution and the FTIR spectrum analysis. The method used in this research was countercurrent system in the extraction process, feed solution preparation process, the thickening process, powder formation process conducted with the aid of Rotavapor- 151 Standard, and testing. The results showed that the tingi bark contains tannin level 70.91\% and non-tannin levels $10.63 \%$. Tannins from tingi bark were classified as procyanidin condensed tannins type and the absorption values obtained maximum value at wavelength $490 \mathrm{~nm}$. The FTIR spectral data indicated that tingi tannins contained hydroxyl group ( $v \mathrm{O}-\mathrm{H} ; \mathrm{v} \mathrm{N}-\mathrm{H})$ in the area (3467.418-3057.025) $\mathrm{cm}^{-1}$, aromatic group ( $\left.v \mathrm{C}-\mathrm{H}\right)$ in the area of 2875,733 $\mathrm{cm}^{-1}, v \mathrm{C}=\mathrm{O}$ (ester group in tanned material) in the area (1747.442-1612.422) $\mathrm{cm}^{-1}, \mathrm{v}-\mathrm{OH}$; $\mathrm{R}$-COO-in the area of $1444.626 \mathrm{~cm}^{-1}$ and $\mathrm{r}\left(\mathrm{SO}_{4}\right)^{2-} ; \mathrm{R}_{-} \mathrm{SO}_{3} ; \mathrm{R}-\mathrm{SO}_{3} \mathrm{H}$ in the area $(1112.823-1062.729) \mathrm{cm}^{-1}$.
\end{abstract}

Keywords: FTIR spectrum, procyanidin, tingi bark, tannin, solution absorption

\section{ABSTRAK}

Kulit kayu tingi (Ceriops tagal) berpotensi sebagai bahan penyamak nabati mengingat kandungan tanin yang tinggi. Tujuan penelitian adalah untuk mengetahui karakterisasi bahan penyamak tingi terhadap kadar tanin, kadar non tanin, tipe tanin, absorpsi larutan tingi dan spektrum FTIR. Metode yang dilakukan meliputi pembuatan ekstrak larutan dengan sistem counter current, preparasi larutan umpan, pemekatan, pembentukan serbuk menggunakan Rotavapor-151 Standard, dan pengujian. Hasil karakterisasi kulit kayu tingi menunjukkan kandungan tanin 70,91\% dan kadar non tanin 10,63\%. Tanin tingi termasuk golongan condensed tannin tipe procyanidin dan absorpsi larutan tingi didapatkan panjang gelombang maksimum $490 \mathrm{~nm}$. Data spektrum FTIR tanin tingi menunjukkan adanya gugus hydroksil (vO-H; vN-H) pada area $(3467,418-3057,025) \mathrm{cm}^{-1}$, gugus aromatik $(\mathrm{rC}-\mathrm{H})$ pada area 2875,733 $\mathrm{cm}^{-1}, \mathrm{rC}=\mathrm{O}$ (ester group in tanned material) pada area $(1747,442-1612,422) \mathrm{cm}^{-1}, \mathrm{v}-\mathrm{OH}$; R-COO- pada area $1444,626 \mathrm{~cm}^{-1}$ dan $\mathrm{v}\left(\mathrm{SO}_{4}\right)^{2-;}$ R-SO $\mathrm{SO}_{3}$ R-SO $\mathrm{S}_{3}$ pada area $(1112,823-1062,729) \mathrm{cm}^{-1}$.

Kata kunci: spektrum FTIR, procyanidin, kulit kayu tingi, tanin, absorpsi larutan.

\section{PENDAHULUAN}

Indonesia kaya akan sumber daya alam yang menyimpan sumber tanin sebagai bahan penyamak nabati. Pohon tingi (Ceriops tagal) merupakan salah satu sumber tanin yang sangat potensial dan pohon ini termasuk jenis mangrove (Rusila et al., 2012) dengan sumber tanin diantaranya terdapat pada kulit kayunya.
Pohon tingi banyak tumbuh di berbagai daerah di Indonesia, diantaranya di Jawa Tengah, Jawa Timur, Sulawesi, dan Kalimantan terutama di daerah pinggir pantai. Kayu tingi dimanfaatkan sebagai kayu bakar sedangkan kulit kayunya digunakan sebagai bahan pewarna batik untuk campuran warna soga (kayu tegeran, kulit kayu tingi, dan jambal). Kulit kayu tingi memberi 
arah warna coklat kemerahan dengan kandungan tanin sebesar 26,5\%. Persentase kandungan tanin tersebut bila dibandingkan dengan kulit kayu avaram, hemlock, oak, dan chestnut cukup tinggi (Nazir, 2008). Mengingat kandungan tanin pada kulit kayu tingi cukup tinggi, maka perlu dilakukan karakterisasi terhadap tanin pada kulit kayu tingi. Hal ini dilakukan untuk mengetahui kualitas tanin terkait kapasitasnya sebagai bahan penyamak nabati. Oleh karena itu kulit kayu tingi diharapkan dapat digunakan sebagai salah satu alternatif untuk bahan penyamak nabati, sehingga kulit kayu tingi dapat dimanfaatkan secara optimal.

Tanin merupakan substansi terpenting yang ada di dalam tumbuhan, terdapat pada bagian kayu, kulit kayu, daun buah, dan akar, yang terjadi secara alami (Mekonnen et al., 2013) dan digunakan sebagai bahan penyamakan kulit (Vieira et al., 2011; Chupin et al., 2013). Selain adanya material tanin dalam tumbuhan, terdapat pula material non tanin antara lain lemak, lilin, resin, terpenoid, asam uronat, pektin, dan protein (Burkhardt et al., 2013). Kandungan non tanin berpengaruh pada sifat ekstrak bahan penyamak. Astringency adalah rasio antara tanin dan non tanin yang merupakan karakteristik utama yang juga berperan dalam menentukan sifat penyamakan dari berbagai jenis ekstrak bahan penyamak (Ahmed et al., 2005).

Tanin secara ilmiah didefinisikan sebagai senyawa polifenol (Ucar et al., 2013; Bharudin et al., 2013) yang mempunyai berat molekul tinggi (500-3000) Dalton (Da), terdiri atas elemen $\mathrm{C}, \mathrm{H}$, dan $\mathrm{O}$ dengan formula empirik $\mathrm{C}_{76} \mathrm{H}_{52} \mathrm{O}_{46}$ dan mempunyai gugus hidroksil dan gugus lainnya (seperti karboksil) sehingga dapat membentuk ikatan-ikatan hidrogen dengan kolagen dan membuat matriks polyphenolic tanning dan makromolekul lainnya di bawah kondisi lingkungan tertentu (Danarto dkk., 2011; Duki et al., 2013).<smiles>O=C(O)c1cc(O)c(O)c(O)c1</smiles>

Gambar 1. Struktur asam gallat.
Pengambilan tanin dilakukan dengan proses ekstraksi, salah satunya adalah metode ekstraksi tanin skala laboratorium dengan teknik yang sederhana. Sebagai pelarut digunakan air dengan temperatur $70-100^{\circ} \mathrm{C}$ (Ping et al., 2011), jika diinginkan untuk mendapatkan tanin dengan kualitas baik maka pelarut yang digunakan adalah aseton-air-bisulfite (Falcao \& Araujo, 2011).

Tanin diklasifikasikan menjadi dua golongan yaitu hydrolyzable tannins (Pyrogallol tannin) dan condensed (catechol) atau flavonoid tannin (Ismarani, 2013; Ucar et al., 2013). Zat penyamak pyrogallol biasanya berwarna kuning kecoklatan. Pyrogallol tannin/hydrolyzable tannins ditemukan dalam daun dan kulit kayu di banyak spesies tanaman seperti myrobalan, divi-divi, chestnut, oak, valonia, sumac, dan tara. Struktur molekul hydrolyzable tanin merupakan hidroksil dari karbohidrat atau phenolic esterified seperti asam gallat (dalam gallotannins) atau asam ellagat (dalam ellagitannins). Struktur asam gallat dapat dilihat pada Gambar 1.

Catechol/condensed tannin dikenal sebagai proanthocyanidins yang merupakan produk polimerisasi flavan-3-ols dan flavan-3,4-diol atau campuran dari dua polimer, yang disebut sebagai flavans (Zhang et al., 2012). Zat penyamak catechol biasanya berwarna coklat kemerahan dan akan membesar molekulnya apabila dipanaskan dalam larutan asam. Proanthocyanidin diklasifikasikan sebagai procyanidin dan prodelphinidin dan yang paling banyak terdapat pada tanaman adalah procyanidin (Ping et al., 2011; Hoong et al., 2010). Struktur flavan seperti pada Gambar 2.

Tumbuhan yang banyak mengandung zat penyamak/tanin catechol adalah gambir, akasia, mimosa, quebracho, dan mangrove. Dalam penyamakan kulit, tanin catechol merupakan bahan penyamak penting dibandingkan dengan tanin pyrogallol. Total tanin nabati yang dikonsumsi oleh industri $65-70 \%$ adalah tanin catechol

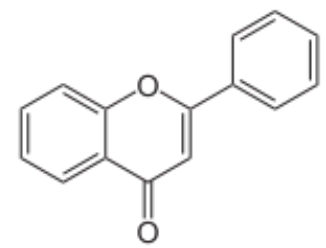

Gambar 2. Struktur flavan. 
(Nazir, 2008). Bahan penyamak nabati yang banyak digunakan oleh industri penyamakan kulit adalah mimosa. Tanin mimosa produk SETA S.A Extrativa Tanino de Acacia Brazil dengan 5 tipe memiliki kadar tanin dan non tanin seperti tertera pada Tabel 1.

Tanin dari kulit kayu tingi (Ceriops tagal) termasuk golongan condensed tannin/catechol tipe procyanidin dan telah dibuktikan dengan uji kualitatif menggunakan ferric chloride dan besi alum yaitu dengan hasil adanya warna spesifik/endapan (Nazir, 2008). Procyanidin adalah anggota proanthocyanidin (atau tanin terkondensasi) golongan flavonoid yang merupakan senyawa oligomer, yang terbentuk dari molekul catechin dan epicatechin. Tanin bakau/mangrove umumnya lebih banyak mengandung procyanidin dibanding dengan prodelphinidin (Oo et al., 2009)

Menurut Musa dan Gasmelseed (2012) untuk menganalisis vegetable tannin dapat menggunakan ultraviolet, fourer transform infrared spectroscopies (FTIR), dan liquid chromatography (LC). Untuk menentukan tipe vegetable tannin digunakan UV spectra dan untuk karakterisasi tanin antara lain dilakukan analisis kadar tanin dan non tanin. Lebih lanjut Nakagawa and Sugita (1999) mengatakan bahwa untuk menunjukkan karakteristik pola absorpsi dari bahan penyamak nabati digunakan fourer transform infrared spectroscopies (FTIR).

Tujuan penelitian adalah untuk mengetahui karakterisasi bahan penyamak tingi terhadap kadar tanin, kadar non tanin, tipe tanin, absorpsi larutan tingi, dan spektrum FTIR.

\section{BAHAN DAN METODE Bahan Penelitian}

Bahan yang digunakan dalam penelitian ini adalah kulit kayu tingi dan serbuk mimosa brand ekstract Cekoslovakia (produk impor/paten) sebagai pembanding.

\section{Peralatan Penelitian}

Alat yang digunakan dalam penelitian ini meliputi alat pencacah kulit kayu (crusher), termometer, Baume meter, Rotavapor R-151 Standard, Piknometer, timbangan Sartorius, Bransonic, water bath magnetic stirrer, Jar test, piranti gelas, dan porselen. Alat untuk pengujian adalah Fourier Transform InfraRed (FTIR) merek Shimadzu.

\section{Metode Penelitian \\ Pembuatan ekstrak larutan}

Kulit kayu tingi (Ceriops tagal) ukuran panjang $5 \mathrm{~cm}$, lebar $2 \mathrm{~cm}$, dan tebal $5 \mathrm{~mm}$ dengan berat $5 \mathrm{~kg}$ dikecilkan ukurannya menggunakan mesin crusher dengan ukuran panjang $16,7 \mathrm{~mm}$, lebar 4,7 $\mathrm{mm}$, dan tebal 1,8 mm. Kemudian kulit kayu tingi dikeringkan di udara terbuka dan diekstrak menggunakan sistem counter current, suhu awal pelarut (air) $80^{\circ} \mathrm{C}$, perbandingan kulit kayu tingi dengan pelarut 1:3, dan dalam waktu 24 jam.

Larutan ekstrak kulit kayu tingi disaring menggunakan kertas saring Whatman 400 mesh. Filtrat yang diperoleh ditampung dalam gelas beker bertutup $4000 \mathrm{ml}$. Untuk menghindari pembusukan larutan ekstrak, sebelum diumpankan dalam labu Rotavapor, larutan dalam posisi tertutup rapat.

\section{Pembuatan puder}

Metode pembuatan puder menggunakan teknik pemekatan larutan ekstrak bahan pewarna alam menggunakan Rotavapor R-151 Standard seperti yang dilakukan Kismolo dkk., (2000). Langkah pertama yaitu pemekatan larutan. Kran unit $R o$ tavapor diatur pada posisi tertutup, kemudian dihubungkan dengan kran pengumpanan dengan wadah larutan ekstrak kulit kayu tingi hasil filtrasi. Unit vakum dihidupkan, dan tekanan dalam labu rotavapor diatur pada tekanan vakum $-45 \mathrm{kPa}$. Kran labu dibuka sehingga larutan ekstrak kayu tingi masuk perlahan-lahan dalam labu Rotavapor sampai volume larutan sebanyak $1000 \mathrm{ml}$. Selanjutnya, unit pemanas dihidupkan dan diatur pada suhu $80^{\circ} \mathrm{C}$, kecepatan putaran labu Rotavapor 10

Tabel 1. Kadar tanin dan non tanin mimosa SETA (n.d) produk dari Brazil.

\begin{tabular}{clcc}
\hline No. & Tipe mimosa & Kadar tanin $(\%)$ & Kadar non tanin (\%) \\
\hline 1. & Natur & 72,5 & 27,0 \\
2. & 2000 & 71,0 & 28,5 \\
3. & Sun & 72,5 & 27,0 \\
4. & Supersol & 72,5 & 27,0 \\
5. & Supersol Light & 71,0 & 28,0 \\
\hline
\end{tabular}


rpm. Setelah suhu larutan dalam labu mencapai $65^{\circ} \mathrm{C}$, tekanan labu diatur sampai diperoleh kondisi larutan mendidih secara konstan tanpa terjadi carry over. Pendidihan dilakukan sampai terbentuk lumpur. Selanjutnya pemanasan dihentikan ketika seluruh permukaan labu Rotavapor tertutup lumpur secara merata.

Untuk pembentukan puder dilakukan pemanasan lanjut terhadap lumpur yang diperoleh menggunakan pemanas magnetic stirrer, pada kecepatan putaran pengaduk $50 \mathrm{rpm}$ sampai diperoleh puder. Puderisasi dilakukan di Laboratorium PTAPB - Batan Yogyakarta.

\section{Pengujian}

Identifikasi kulit kayu tingi (metode uji: SNI 06-6051-1999) meliputi uji kadar air, kadar total ekstrak, kadar total larut, kadar zat bukan penyamak (non tanin), dan kadar zat penyamak (tanin). Uji serbuk tingi hasil puderisasi (metode uji: SNI 066051-1999) meliputi uji kadar total ekstrak, kadar total larut, kadar zat bukan penyamak (non tanin), kadar zat penyamak (tanin). Dilakukan uji FTIR untuk mengetahui gugus fungsional serbuk tingi hasil puderisasi dengan serbuk mimosa produk paten sebagai pembanding.

\section{HASIL DAN PEMBAHASAN Identifikasi Kulit Kayu Tingi}

Hasil identifikasi kulit kayu tingi yang akan diekstrak meliputi uji kadar air, kadar total ekstrak, kadar total larut, kadar zat bukan penyamak (non tanin) dan kadar zat penyamak (tanin) disajikan pada Tabel 2.

\section{Ekstraksi Kulit Kayu Tingi}

Hasil ekstraksi kulit kayu tingi (hasil penelitian) dibandingkan dengan hasil ekstraksi kulit kayu akasia hasil penelitian Waskito dkk. (2011) disajikan pada Tabel 3.

Dari Tabel 3 dapat dilihat bahwa jumlah ekstrak yang diperoleh dari ekstraksi kulit kayu tingi sebesar 151,51 gram dan kulit kayu akasia sebesar 153,00 gram, nilainya hampir sama. Pada Tabel 3 juga dapat dilihat bahwa ternyata kadar tanin yang dihasilkan oleh kulit kayu tingi $(70,91 \%)$ lebih tinggi dibandingkan dengan tanin dari kulit kayu akasia $(52,59 \%)$.

Hasil ekstraksi tanin (puder) dari kulit kayu tingi (Ceriops tagal) kemudian dibandingkan dengan mimosa produk paten (puder) disajikan pada Tabel 4. Dari Tabel 4 dapat diketahui bahwa kadar tanin tingi (hasil penelitian) dibandingkan dengan kadar tanin mimosa produk paten yaitu Natur, 2000, Sun, Supersol dan Supersol Light, ternyata mutunya setingkat yaitu dengan kadar tanin sekitar $70 \%$. Kondisi tersebut dapat disebabkan karena proses penyarian mulai dari ekstraksi pembuatan larutan sampai dengan puderisasi suhu yang digunakan cukup memadai, artinya masih dalam batas kondisi proses ekstraksi tanin yang baik, tidak kurang $70^{\circ} \mathrm{C}$ dan tidak lebih dari $100^{\circ} \mathrm{C}$. Hal ini sesuai dengan pendapat Ping et al. (2011) bahwa pengambilan tanin dilakukan dengan proses ekstraksi menggunakan air sebagai pelarut dengan temperatur $70-100^{\circ} \mathrm{C}$. Bila suhu ekstraksi di atas $100^{\circ} \mathrm{C}$ pelarut air yang digunakan akan menguap sehingga zat ekstraktif akan mengendap kembali meningkatkan viskositas tanin yang diperoleh. Hasil ekstraksi berwarna lebih gelap dan akan menurunkan kualitas tanin yang diperoleh. Sebaliknya bila suhu ekstraksi di bawah $70^{\circ} \mathrm{C}$ menjadi tidak efisien, karena jumlah ekstrak yang terlarut dalam air relatif sedikit. Pemanasan terlalu lama pada suhu yang terlalu tinggi akan menghasilkan tanin yang lebih rendah karena tanin akan teroksidasi dan terhidrolisis menjadi asamasam polifenol yang tidak dapat larut dalam air. Semakin lama waktu ekstraksi maka kesempatan bersentuhan antara bahan dan pelarut semakin besar, sehingga hasilnya akan bertambah. Proses ini akan berlangsung terus sampai konsentrasi bahan dan pelarut mencapai titik jenuh. Demikian juga suhu yang digunakan tidak terlalu tinggi untuk mencegah terjadinya oksidasi yang akan

Tabel 2. Hasil identifikasi kulit kayu tingi (Ceriops tagal).

\begin{tabular}{clc}
\hline No. & Macam uji & Hasil uji, \% \\
\hline 1. & Kadar air & 15,36 \\
2. & Kadar total ekstrak & 12,87 \\
3. & Kadar total larut & 12,76 \\
4. & Kadar zat bukan penyamak (non tanin) & 1,30 \\
5. & Kadar zat penyamak nabati (tanin) & 11,46 \\
\hline
\end{tabular}


Tabel 3. Hasil ekstraksi kulit kayu tingi dan ekstraksi kulit kayu akasia.

\begin{tabular}{cccccc}
\hline No. & Jenis kayu & $\begin{array}{c}\text { Berat kulit } \\
\text { kayu }(\mathrm{kg})\end{array}$ & $\begin{array}{c}\text { Volume dan } \\
\text { kepekatan larutan }\end{array}$ & $\begin{array}{c}\text { Jumlah puder } \\
(\text { gram })\end{array}$ & $\begin{array}{c}\text { Kadar tanin } \\
(\%)\end{array}$ \\
\hline 1 & Tingi & 4 & 4,0 liter, $3^{\circ} \mathrm{Be}$ & 151,51 & 70,91 \\
2 & Akasia & 5 & 3,7 liter, $9^{\circ} \mathrm{Be}$ & 153,00 & 52,59 \\
\hline
\end{tabular}

Tabel 4. Hasil ekstraksi tanin dari kulit kayu tingi (Ceriops tagal).

\begin{tabular}{clcc}
\hline No. & Bahan penyamak nabati & Kadar tanin $(\%)$ & Kadar non tanin $(\%)$ \\
\hline 1. & Tingi & 70,91 & 10,63 \\
2. & Natur (Mimosa) & 72,50 & 27,0 \\
3. & 2000 (Mimosa) & 71,00 & 28,5 \\
4. & Sun (Mimosa) & 72,50 & 27,0 \\
5. & Supersol (Mimosa) & 72,50 & 27,0 \\
6. & Supersol Light (Mimosa) & 71,00 & 28,0 \\
\hline
\end{tabular}

mengakibatkan warna sari penyamak menjadi gelap.

Bahan penyamak nabati sangat rumit karena mempunyai komposisi kimia dan astringency tertentu yang dapat mempengaruhi kualitas kulit yang dihasilkan (Mahdi et al., 2006; Gonultas \& Ucar, 2012). Astringency merupakan ratio antara tanin dan non tanin. Astringency adalah karakteristik utama yang menentukan sifat penyamakan dari berbagai jenis ekstrak bahan penyamak (Ahmed, et al., 2005). Material non tanin antara lain lemak, lilin, resin, terpenoid, asam uronat, pektin, dan protein (Burkhardt et al., 2013). Dari Tabel 4 terlihat bahwa rasio tanin/ non tanin dari bahan penyamak tingi sebesar 6,67 sedang untuk mimosa produk paten rata-rata 2,6. Kemurnian tanin atau ratio tanin/non tanin adalah baik jika nilainya $\geq 0,6$. Astringent tinggi akan mengikat dengan kuat dan cepat bereaksi dengan serat kulit, sehingga penetrasi ke serat kulit perlu dikontrol $\mathrm{pH}$ dan konsentrasinya, agar kulit yang dihasilkan tidak keras dan kasar. Sebaliknya, bila astringent kurang (less astringent), tanin menembus serat kulit lebih ekstensif dan reaksinya lemah karena poor tanning dan lebih rentan terhadap kerusakan mikrobiologi (Ahmed, et al., 2005).

\section{Hasil Spektrum FTIR}

Data spektrum FTIR tingi (A) dan mimosa (B) disajikan pada Gambar 3. Pada spektrum FTIR tingi (A) menunjukkan adanya gugus hidroksil (vO-H; vN-H) pada area $(3467,418-3057,025)$ $\mathrm{cm}^{-1}$, gugus aromatik ( $\left.\mathrm{rC}-\mathrm{H}\right)$ pada area 2875,733 $\mathrm{cm}^{-1}, \mathrm{vC}=\mathrm{O}$ (ester group in tanned material) pada area $(1747,442-1612,422) \mathrm{cm}^{-1}, \mathrm{v}-\mathrm{OH}$; R-COOpada area $1444,626 \mathrm{~cm}^{-1}$ dan $\mathrm{v}\left(\mathrm{SO}_{4}\right)^{2-}$; R-SO $\mathrm{R}-\mathrm{SO}_{3} \mathrm{H}$ pada area $(1112,823-1062,729) \mathrm{cm}^{-1}$.

Pada spektrum FTIR Mimosa (B) menunjukkan adanya gugus hidroksil ( $\mathrm{rO}-\mathrm{H} ; \mathrm{vN}-\mathrm{H})$ pada area $(3334,740-3016,529) \mathrm{cm}^{-1}$, gugus aromatik ( $\vee \mathrm{C}-\mathrm{H})$ pada area $2950,636 \mathrm{~cm}^{-1}, \mathrm{v}-\mathrm{OH}$; R-COO- pada area $1454,236 \mathrm{~cm}^{-1}$ dan $\mathrm{v}\left(\mathrm{SO}_{4}\right)^{2-}$; $\mathrm{R}-\mathrm{SO}_{3} ; \mathrm{R}^{-} \mathrm{SO}_{3} \mathrm{H}$ pada area $(1159,137-1028,034)$ $\mathrm{cm}^{-1}$.

Data pada Tabel 5 menunjukkan adanya persamaan gugus-gugus fungsional pada tanin

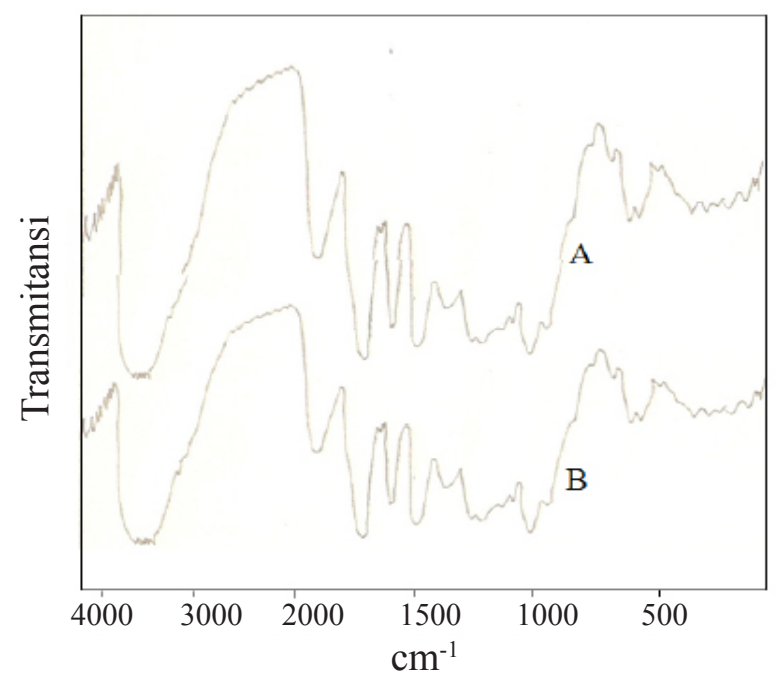

Gambar 3. Spektrum FTIR: (A) tingi, (B) mimosa. 
Tabel 5. Data analisis kualitatif spektrum FTIR.

\begin{tabular}{lll}
\hline Gugus fungsional & \multicolumn{1}{c}{ Bahan penyamak tingi } & Bahan penyamak mimosa \\
\hline $\mathrm{N}-\mathrm{H} ; \mathrm{O}-\mathrm{H}$ (hidroksil) & $(3467,418-3057,025) \mathrm{cm}^{-1}$ & $(3334,740-3016,529) \mathrm{cm}^{-1}$ \\
$\mathrm{C}-\mathrm{H}$ (gugus aromatik) & $2875,733 \mathrm{~cm}^{-1}$ & $2950,636 \mathrm{~cm}^{-1}$ \\
$\mathrm{C}=\mathrm{O}$ (karbonil) & $(1747,442-1612,422) \mathrm{cm}^{-1}$ & - \\
$-\mathrm{OH} ; \mathrm{R}-\mathrm{COO}-$ & $1444,626 \mathrm{~cm}^{-1}$ & $1454,236 \mathrm{~cm}^{-1}$ \\
$\left(\mathrm{SO}_{4}\right)^{2-} ; \mathrm{R}-\mathrm{SO}_{3} ; \mathrm{R}^{-\mathrm{SO}_{3} \mathrm{H}}$ & $(1112,823-1062,729) \mathrm{cm}^{-1}$ & $(1159,137-1028,034) \mathrm{cm}^{-1}$ \\
\hline
\end{tabular}

tingi dan mimosa seperti gugus hidroksil, aromatik, karbonil dan lainnya yang keduanya merupakan bahan penyamak nabati. Menurut Danarto dkk. (2011), unsur tanin utamanya adalah gugus hidroksil dan ada gugus lainnya seperti karboksil. Lebih lanjut dikatakan oleh Valeika et al. (2010) bahwa vibrasi dalam range (33002500) $\mathrm{cm}^{-1}$ adalah atribut untuk gugus hidrogen dari gabungan gugus-gugus fungsional $\mathrm{O}-\mathrm{H} ; \mathrm{N}-\mathrm{H}$; dan C- H.

\section{KESIMPULAN}

Berdasar hasil karakterisasi kulit kayu tingi sebagai bahan penyamak nabati dapat disimpulkan bahwa kadar tanin kulit kayu tingi (puder) adalah $70,91 \%$ dan kadar non tanin $10,63 \%$. Tanin tingi (Ceriops tagal) termasuk golongan condensed tannin tipe procyanidin. Data spektrum FTIR tanin tingi menunjukkan adanya gugus hidroksil (rO-H; rN-H) pada area $(3467,418-3057,025)$ $\mathrm{cm}^{-1}$, gugus aromatik ( $\left.\mathrm{rC}-\mathrm{H}\right)$ pada area 2875,733 $\mathrm{cm}^{-1}, \mathrm{VC}=\mathrm{O}$ (ester group in tanned material) pada area $(1747,442-1612,422) \mathrm{cm}^{-1}, \mathrm{v}-\mathrm{OH} ; \mathrm{R}-\mathrm{COO}^{-}$ pada area $1444,626 \mathrm{~cm}^{-1}$ dan $\mathrm{r}\left(\mathrm{SO}_{4}\right)^{2-} ; \mathrm{R}^{-} \mathrm{SO}_{3}$; $\mathrm{R}-\mathrm{SO}_{3} \mathrm{H}$ pada area $(1112,823-1062,729) \mathrm{cm}^{-1}$ yang serupa dengan mimosa sehingga dapat digunakan sebagai alternatif bahan penyamak nabati.

\section{UCAPAN TERIMA KASIH}

Penulis mengucapkan terima kasih kepada Kepala BBKKP atas fasilitas yang diberikan selama penelitian dan kepada semua fihak yang telah membantu jalannya penelitian ini.

\section{DAFTAR PUSTAKA}

Ahmed, M., Khirstova, P., \& Icho, G. (2005). Comparative study of tannins of Acacia nilotica an indigenous tanning material in Sudan with Acacia mearnsii. Suranaree Journal of Society Technology, 12(4), 259-265.

Bharudin, M. A., Zakaria, S., \& Chia, C. H. (2013). Condensed tannins from Acacia mangium bark: Characterization by spot tests and FTIR. Proceedings of the Universiti Kebangsaan Malaysia, Faculty of Science and Technology 2013 Postgraduate Colloquium, 1571(1), 153157.

Burkhardt, S., Kumar, L., Chandra, R., \& Saddler, J. (2013). How effective are traditional methods of compositional analysis in providing an accurate material balance for a range of softwood derived residues?. Biotechnology and Biofuels, 6, 90.

Chupin, L., Motillon, C., Charrier-El Bouhtoury, F., Pizzi, A., \& Charrier, B. (2013). Characterisation of maritime pine (Pinus pinaster) bark tannins extracted under different conditions by spectroscopic methods, FTIR and HPLC. Industrial Crops and Products, 9, 897-903.

Danarto., Y. C., Stefanus, A. P., \& Zery, A. P. (2011). Pemanfaatan tanin dari kulit bakau sebagai pengganti gugus fenol pada resin fenol formaldehid. Dalam Prosiding Seminar Nasional Teknik Kimia: Kejuangan Pengembangan Teknologi Kimia untuk Pengolahan Sumber Daya Alam Indonesia. Yogyakarta, Indonesia: UPN Veteran.

Duki, A., Antunes, A. P. M., Covington, A. D., \& Guthrie-Strachan, J. (2013). The stability of metal-tanned and semi-metal tanned collagen in XXXII Congress of IULTCS 2013. Istambul, Turkey: IULTC.

Falcão, L., \& Araújo, M. E. M. (2011). Tannins characterisation in new and historic vegetable tanned leathers fibres by spot tests. Journal of Cultural Heritage, 12(2), 149-156.

Gonultas, O., \& Ucar, M. B. (2012). Chemical composition of some commercial tannins produced in Turkey. In Proceedings of the 55th International Convention of Society of Wood Science and Technology. Beijing, China: Society of Wood Science and Technology.

Hoong, Y. B., Pizzi, A., Tahir, M. P., \& Pasch, H. (2010). Characterization of Acacia mangium polyflavonoid tannins by MALDI-TOF mass spectrometry and CP-MAS 13 C NMR. European Polymer Journal, 46(6), 1268-1277.

Ismarani, I. (2013). Potensi senyawa tanin dalam menunjang produksi ramah lingkungan. Jurnal Agribisnis dan Pengembangan Wilayah, 3(2), 46- 
55.

Kismolo, E., Prayitno, P., Kasmudjiastuti, E., \& Widhiati, W. (2000). Teknik pemekatan larutan ekstrak bahan pewarna alam menggunakan rotavapor. Dalam Prosiding Seminar Nasional Industri Kulit, Karet dan Plastik. Yogyakarta, Indonesia: Balai Besar Kulit, Karet, dan Plastik.

Mahdi, H., Palmina, K., \& Glavtch, I. (2006). Characterization of Acacia nilotica as an indigenous tanning material of Sudan. Journal of Tropical Forest Science, 18(3), 181-187.

Mekonnen, D., Habtamu, S., Sathiyamoorthy, M., \& Selvi, V. (2013). Preparation of eco-friendly leather by process modifications to make pollution free tanneries. Journal of Engineering Computers and Applied Sciences, 2(5), 17-22.

Musa, A. E., \& Gasmelseed, G. A. (2012). Characterization of Lawsonia inermis (Henna) as vegetable tanning material. Journal of Forest Products and Industries, 1(2), 35-40.

Nakagawa, K., \& Sugita, M. (1999). Spectroscopic characterization and molecular weight of vegetable tannins, Journal of the Society of Leather Technologists and Chemists, 83(5), 261264.

Nazir, F. (2008). Mangrove studies: A source of tanning material. Reviews the used of mangrove as an ecologically friendly tanning material. Leather International, April 2008.

Oo, C. W., Kassim, M. J., \& Pizzi, A. (2009). Characterization and performance of Rhizophora apiculata mangrove polyflavonoid tannins in the adsorption of copper (II) and lead (II). Industrial Crops and Products, 30(1), 152-161.

Ping, L., Pizzi, A., Guo, Z. D., \& Brosse, N. (2011). Condensed tannins extraction from grape pomace: characterization and utilization as wood adhesives for wood particleboard. Industrial Crops and Products, 34(1), 907-914.
Rusila, N.Y., Khazali, M., \& Suryadipura, I. (2012). Panduan Pengenalan Mangrove di Indonesia. Bogor, Indonesia: Ditjen PHKA dan Wetlands International Indonesia Programme.

SETA. (n.d). Product Specifications. Brazil: SETA S.A. Extrativa Tanino De Acacia.

Ucar, M. B., Ucar, G., Pizzi, A., \& Gonultas, O. (2013). Characterization of Pinus brutia bark tannin by MALDI-TOF MS and $13 \mathrm{C}$ NMR. Industrial Crops and Products, 49, 697-704.

Valeika, V., Sirvaityte, J., \& Beleska, K. (2010). Estimation of chrome-free tanning method suitability in conformity with physical and chemical properties of leather. Materials ScienceMedziagotyra, 16(4), 330-336.

Vieira, M. C., Lelis, R. C. C., da Silva, B. C., \& de Lima Oliveira, G. (2011). Tannin extraction from the bark of Pinus oocarpa var. oocarpa with sodium carbonate and sodium bisulfite. Floresta e Ambiente, 18(1), 1-8.

Waskito, S., Herminiwati, H., Purwanti, M. H., Prayitno, P., Dwiningsih, D., Sardjo, S., Hartatik, H., Margono, M., \& Suryanto, B. (2011). Laporan Penelitian Pembuatan Bahan Penyamak Nano Nabati. Yogyakarta, Indonesia: Balai Besar Kulit, Karet, dan Plastik.

Zhang, L. L., Wang, Y. M., Wu, D. M., Xu, M., \& Chen, J. H. (2012). Study on the structure of mangrove polyflavonoid tannins with MALDI-TOF Mass Spectrometry and NMR. Advanced Materials Research, 554, 1988-1993. 
